Сучасна траєкторія розвитку науково-технічного прогресу в Україні та світі

DOI https://doi.org/10.36059/978-966-397-247-3-3

Літвак О. $A$.

кандидат економічних наук, доцент, доцент кафедри екології та природоохоронних технологій

Національний університет кораблебудування імені адмірала Макарова

м. Миколаїв, Україна

\title{
ЗЕЛЕНА ЕНЕРГЕТИКА ЯК КЛЮЧОВИЙ ЕЛЕМЕНТ НИЗЬКОВУГЛЕЦЕВОГО РОЗВИТКУ: СВІТОВІ ТЕНДЕНЦІЇ І ПЕРСПЕКТИВИ ДЛЯ УКРАЇНИ
}

Дослідження присвячено аналізу процесів формування низьковуглецевого розвитку в країнах світу та в Україні. Визначено, що низьковуглещевий розвиток може бути досягнутий за рахунок скорочення частки джерел енергії на основі викопного палива і збільшення обсягів використання відновлювальних джерел енергії, а також за допомогою заходів енергоефективності. Останні роки простежується світова тенденція щодо підвищення конкурентоздатності відновлюваної енергетики, особливо в секторі вітрової та сонячної енергії. Обгрунтовано, що державна політика відіграє важливу роль у трансформації енергетичних систем розвинених країн світу. Шляхом застосування фіскальних інструментів, формування галузевих стандартів уряд здатний стимулювати розвиток зеленої енергетики.

Визначено, що для України низьковуглецевий розвиток має стати основною моделлю національної економіки $i$ сприяти економічному та соціальному розвитку. В Україні прийнято ряд законодавчо-нормативних актів в енергетичній сфері, які відповідають вимогам Паризької угоди про зміну клімату $i$ визначають політики і заходи зі скорочення питомого споживання вуглеводневого палива і підвищення енергоефективності економіки. Сприятливі природно-кліматичні умови України, ефективне залучення та використання інвестицій нададуть можливість в повній мірі реалізувати потенціал відновлюваної енергетики в Украӥні з метою забезпечення кліматичної стійкості і формування процесу економічного зростання. 
Сучасна траєкторія розвитку науково-технічного прогресу в Україні та світі

\section{Вступ}

Сучасний економічний розвиток характеризується високим споживанням енергії, інтенсивним забрудненням навколишнього середовища і значним рівнем викидів парникових газів внаслідок використання викопних видів палива, що призводить до ряду екологічних проблем, таких як глобальне потепління, дефіцит енергетичних ресурсів і загроза екологічній безпеці. При цьому виникають гострі суперечності між екологічними проблемами та економічним розвитком. Такі протиріччя є обмежуючим фактором соціально-економічного розвитку, і зумовлюють необхідність переходу на шлях низьковуглецевого розвитку, скорочення глобальних викидів парникових газів 3 метою пом'якшення наслідків зміни клімату. Така тенденція поступово стає новою точкою зростання світової економіки.

В умовах глобальних кліматичних викликів країни світу змушені планувати свій розвиток з урахуванням кліматичних ризиків і завдань боротьби зі зміною клімату. У світі стрімко розвиваються екологічно і кліматично чисті інноваційні технології виробництва електроенергії. У зв'язку з реалізацією Паризької угоди питання ефективності використання енергії та ії виробництво на основі низьковуглецевих або безвуглецевих джерел $є$ вельми актуальними.

Важливість низьковуглецевого розвитку обумовлена не тільки екологічними проблемами, а також і тим, що це основа, яка дозволяє з економічної точки зору подивитися на такі питання, як пом'якшення наслідків зміни клімату, енергозбереження, енергоефективність та раціональне використання природних ресурсів.

Основи концепції низьковуглецевого розвитку були закладені у 1992 р. в Рамковій конвенції ООН про зміну клімату (United Nations Framework Convention on Climate Change), метою якої є стабілізація концентрацій парникових газів в атмосфері [1]. Досить часто використовують взаємнозамінні терміни такі, як «низьковуглецевий розвиток», «низковуглецева економіка», «низьковуглецева стратегія розвитку», «стратегія розвитку 3 низьким рівнем викидів» або «низьковуглецевий план розвитку».

Поняття низьковуглецевого розвитку отримало в останні роки широке поширення як в офіційних документах, так і в дослідженнях. В деяких джерелах низьковуглецевий розвиток розглядають як 
варіант концепції сталого розвитку, націлений на запобігання катастрофічних наслідків глобальної зміни клімату.

За визначенням Європейської Ради 3 відновлювальної енергетики (European Renewable Energy Council, EUREC) низьковуглецевий розвиток - це заміна викопного палива низьковуглецевої енергією на основі збереження економічного зростання і підвищення добробуту населення [2]. У дослідженні Міжнародної організації праці (International Labour Organization, ILO) низьковуглецевий розвиток визначено як спосіб розвитку, який спрямований на досягнення низьковуглецевої економіки за рахунок процесу декарбонізації, одночасно сприяючи сталому розвитку та боротьбі зі зміною клімату [3].

У Четвертій доповіді «Зміни клімату, 2014» Міжурядової групи експертів зі зміни клімату (Intergovernmental Panel on Climate Change, IPCC) під низьковуглецевим розвитком (низьковуглецевою економікою) розуміється нова соціально-економічна і технологічна система, націлена на скорочення викидів парникових газів (в порівнянні $з$ традиційною економікою) без шкоди для темпів соціально-економічного розвитку [4].

Міжурядовою групою експертів зі зміни клімату було визнано, що для того, щоб глобальне збільшення середньої приземної температури повітря в порівнянні з доіндустріальним значенням було обмежено $2^{\circ} \mathrm{C}$, необхідно знизити глобальні викиди $\mathrm{CO}_{2}$ до 2050 р. на $50 \%$ в порівнянні 31990 р. і стабілізувати їх концентрацію на рівні $450 \mathrm{ppm}$. В цьому випадку рівень концентрація всіх парникових газів буде приблизно 550 ppm в $\mathrm{CO}_{2}$-еквівалента.

Використовуючи результати дослідження Ніколаса Стерна, що наведені у доповіді «Економіка зміни клімату», можна визначити принципи, на яких спирається низьковуглецевий розвиток:

- відокремлення економічного зростання від зростання споживання енергії та викидів парникових газів і інших забруднюючих речовин, завдяки технологічним інноваціям, зміні інфраструктури та моделі поведінки. В якості індикатора ефекту розмежування (ефекту декаплінга) може служити показник зниження енергоємності та вуглецеємності ВВП;

- досягнення ключових цілей сталого розвитку, що передбачає економічне зростання, створення робочих місць та інші соціально-економічні цілі, скорочення споживання ресурсів i посилення науково-технічного прогресу [5]. 
Сучасна траєкторія розвитку науково-технічного прогресу в Україні та світі

Таким чином, основну роль у формуванні низьковуглецевого розвитку на глобальному рівні і в більшості країн світу має відігравати зниження споживання вуглецевмісного викопного палива, розвиток відновлюваних джерел енергії і заходи енергоефективності в різних галузях виробництва і споживання. При цьому конкретні шляхи формування i впровадження низьковуглецевих стратегій можуть відрізнятися в залежності від рівня соціально-економічного розвитку, ресурсних та інших особливостей окремих країн.

\section{1. Світові тенденції переходу до низьковуглецевого розвитку}

Одним 3 важливих інструментів переходу до низьковуглецевого розвитку є регулювання викидів парникових газів. Це пов'язано 3 інтересами енергетичної, екологічної та кліматичної політики, що $€$ одним 3 визначальних чинників сталого соціально-економічного розвитку.

Питання зміни клімату і глобального потепління $\epsilon$ важливою проблемою для всіх країн світу і вимагає серйозних рішень. Явище парникового ефекту дуже складне i $\epsilon$ одним 3 істотних кліматичних факторів. Завдяки присутності парникових газів створюються умови для існуючого на Землі біологічного різноманіття. За багато мільйонів років вміст газів, що викликають парниковий ефект, встановився на значенні, що дозволяє підтримувати теплову рівновагу на планеті. До основних парникових газів відносять $\mathrm{CO}_{2}, \mathrm{CH}_{4}, \mathrm{~N}_{2} \mathrm{O}, \mathrm{SF}_{6}$ та фреони [6]. Ці гази сильно розрізняються своєю концентрацією в атмосфері. Підвищення сумарної концентрації парникових газів в атмосфері призводить до посилення парникового ефекту і, як наслідок, до підвищення глобальної температури. В парниковому ефекті важливу роль відіграє вуглекислий газ, обсяг якого за останній час збільшився до 20-26\%.

Три чверті вкладу в глобальну емісію парникових газів дає вуглекислий газ. Основним джерелом антропогенної емісії $\mathrm{CO}_{2}$ в атмосферу $є$ енергетика. Більшу частину енергії, необхідної для виробництва електроенергії, опалення будинків, роботи транспорту, забезпечує викопне паливо: нафта, природний газ і вугілля, при спалюванні якого в атмосферу надходить 95\% всіх антропогенних викидів вуглекислого газу. Значна кількість $\mathrm{CO}_{2}$ виділяється при згорянні й розкладанні деревини, при 
Сучасна траєкторія розвитку науково-технічного прогресу в Україні та світі

вирубуванні лісів, в результаті змін в землекористуванні, ерозії грунтів і в процесі ведення сільського господарства.

В рейтингу країн 3 найбільшими обсягами викидів вуглекислого газу від спалювання палива за 2020 рік Китай знаходиться на першому місці. На другому місці - США. Викиди вуглекислого газу в цих двох країнах забезпечують 45,5\% загальносвітового обсягу. Китай та США $\epsilon$ найбільшими споживачами викопного палива для виробництва теплової енергії, але останні роки обсяги викидів скорочуються завдяки подальшому переходу до використання природного газу, що вважається меншою загрозою для кліматичних змін і екологічної безпеки (табл. 1).

Таблиця 1

Країни з найбільшими обсягами викидів вуглекислого газу від спалювання палива за 2020 рік [7]

\begin{tabular}{|c|c|c|c|}
\hline Країна & $\begin{array}{c}\text { Обсяги } \\
\text { викидів, } \\
\text { млн. тонн }\end{array}$ & $\begin{array}{c}\text { Питома вага } \\
\text { у світовому } \\
\text { обсязі викидів, } \\
\text { \% }\end{array}$ & $\begin{array}{c}\text { 4.1.1.1 } \\
\text { Вуглецевий } \\
\text { коефіцієнт, } \\
\text { т Со } / \text { т н.e. }\end{array}$ \\
\hline Китай & 9717 & 31,3 & 2,87 \\
\hline США & 4405 & 14,2 & 2,15 \\
\hline Індія & 2191 & 7,1 & 4,41 \\
\hline Росія & 1619 & 5,2 & 2,21 \\
\hline Японія & 979 & 3,2 & 2,54 \\
\hline Іран & 619 & 2,0 & 2,31 \\
\hline Германія & 617 & 2,0 & 1,54 \\
\hline Південна Корея & 570 & 1,8 & 2,02 \\
\hline Індонезія & 566 & 1,8 & 2,52 \\
\hline Канада & 516 & 1,7 & 1,02 \\
\hline Саудівська Аравія & 492 & 1,6 & 2,35 \\
\hline
\end{tabular}

Згідно даних Щорічника світової енергетичної статистики Enerdata в 2020 р. показник викидів вуглекислого газу в світовому енергетичному секторі складає 31,06 млрд тонн. Обсяги викидів вуглекислого газу в світі знизилися порівняно 3 попередніми роками. Стабільний рівень викидів відбувається, завдяки зусиллям, які вживаються розвиненими країнами для відмови від вироблення енергії на основі викопного палива та переходу на ввідновлювані джерела енергії і природний газ. Згідно інформації Міжнародного енергетичного агентсва (International Energy Agency, 
Сучасна траєкторія розвитку науково-технічного прогресу в Україні та світі

IEA), більше $80 \%$ нового попиту на викопне паливо припадатиме на Китай та інші азіатські країни (рис. 1).

Внаслідок специфіки структури енергоресурсів Китаю і деяких країн Азії (переважання запасів вугілля або нафтогазових родовищ) ще довгий час буде дуже складно перевести структуру енергоспоживання, засновану на використанні викопного палива на низьковуглецеве виробництво.

У 2020 р. відбулося скорочення викидів $\mathrm{CO}_{2}$ в енергетичному секторі країн світу на 4,9 \% порівняно з 2019 роком. В першу чергу, це повязано зі спалахом COVID-19, особливо в першій половині року, коли карантинні заходи, обмеження в сфері транспорту та уповільнення темпів економічного зростання в багатьох регіонах світу призвели до істотного скорочення споживання нафти в транспортному секторі. Падіння споживання нафти становило приблизно три чверті загального падіння попиту на енергію. Викиди $\mathrm{CO}_{2}$ також зменшилися в енергетичному секторі через зниження попиту на електроенергію і в результаті зниження вуглецевого коефіцієнту (обсяг викидів $\mathrm{CO}_{2}$ на спожиту тонну нафтового еквівалента), що переважно зумовлено переходом з вугілля на газ і збільшенням частки відновлюваних джерел енергії в світовому енергетичному балансі.

Зниження енергоспоживання і неухильне зростання в сфері виробництва електроенергії з відновлюваних ресурсів сприяли скороченню вироблення з теплових джерел (особливо з вугілля) i зменшення споживання викопного палива в енергетичному секторі. В основному обсяг викидів зменшився в США (-11\%) і Європі (-11\%, спад в Німеччині, Іспанії та Великобританії). У Китаї ж, навпаки, викиди $\mathrm{CO}_{2}$ ростуть вже четвертий рік поспіль $(+1,6 \%)$ через швидке відновлення попиту на електроенергію і стабільний рівень ії виробництва на вугільних електростанціях [7].

Зростання матеріального виробництва світової економіки обумовлене збільшенням споживання паливно-енергетичних ресурсів, які відносяться до стратегічних видів мінеральної сировини. Ефективність використання паливно-енергетичних ресурсів в економіці країн - один з найважливіших показників рівня розвитку економіки держави, фактор задоволення постійного зростання потреб у паливі, тепловій та електричній енергії, забезпечення енергетичної безпеки, поліпшення екологічної обстановки. 


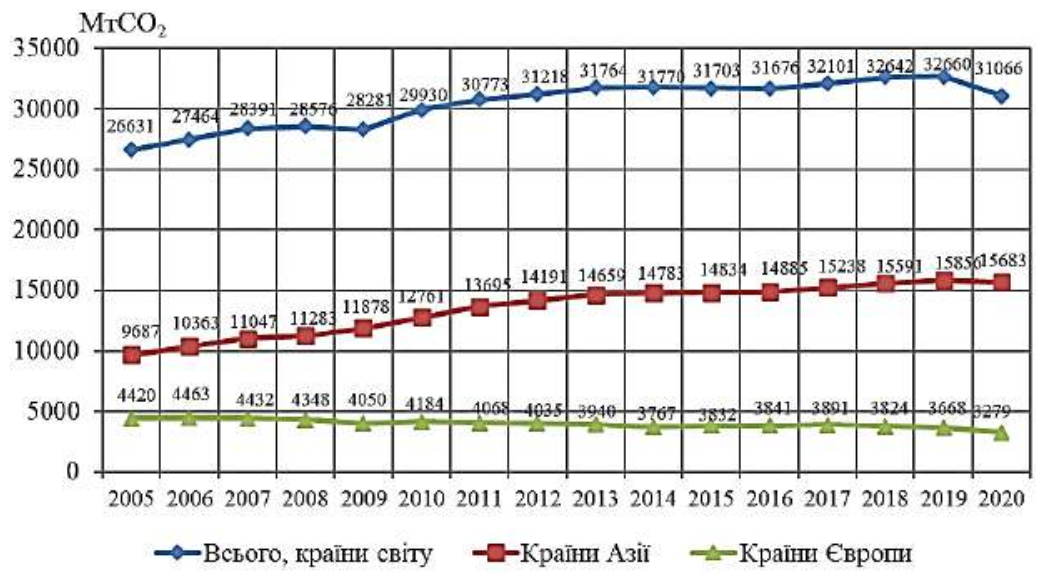

\section{Рис. 1. Динаміка викидів $\mathrm{CO}_{2}$ в енергетичному секторі країн світу за 2005-2020 роки}

Неефективне використання паливно-енергетичних ресурсів призводить до значних втрат в економіці, погіршує екологічну обстановку на місцевому, регіональному і глобальному рівнях. В якості одного з показників, що характеризують на макрорівні ефективність використання паливно-енергетичних ресурсів в світовій практиці, застосовується енергоємність валового внутрішнього продукту.

Енергоємність визначається шляхом ділення обсягу первинних енергоресурсів, що споживаються за певний період в країні, на обсяг валового внутрішнього продукту, виробленого за той же період. Тобто це інтенсивність використання енергії на одиницю ВВП. При цьому всі види енергоресурсів призводять до умовної одиниці виміру, в якості якої може бути прийнята або тонна (кілограм) умовного палива, або тонна (кілограм) нафтового еквівалента. ВВП визначається у доларах при за постійним паритетом купівельної спроможності.

У 2020 р. енергоємність в світі скоротилася на 0,4\%, що набагато менше, ніж в попередні кілька років (в середньому -1,5\% на рік в період з 2000 по 2019 роки). За таких обставин досить складно утримати підвищення світової температури в межах $2^{\circ} \mathrm{C}$ знову. Оскільки для досягнення цієї мети потрібно домогтися скорочення до $3,5 \%$ на рік. Основною причиною такого 
уповільнення $є$ економічний спад у 2020 р., який негативно вплинув на економічну активність і не дозволив пропорційно скоротити споживання електроенергії. Показники енергоємності ВВП в країнах світу сильно розрізняються, що відображає різницю в економічній структурі та досягнення в сфері підвищення енергоефективності. За період 3 2000-2020 роки країни Європейського Союзу і США скорочують енергоємність приблизно до $2 \%$ на рік. Цьому сприяють заходи щодо підвищення енергоефективності і впровадження промислових технологій 3 меншим питомим енергоспоживанням. Китай має більш високий показник енергоємності порівняно 3 середнім світовим значенням. Хоча у 2020 p. ця країна спожила на $43 \%$ електроенергії менше, ніж у 2000 р., але все одно на 27\% більше середнього світового показника (рис. 2).

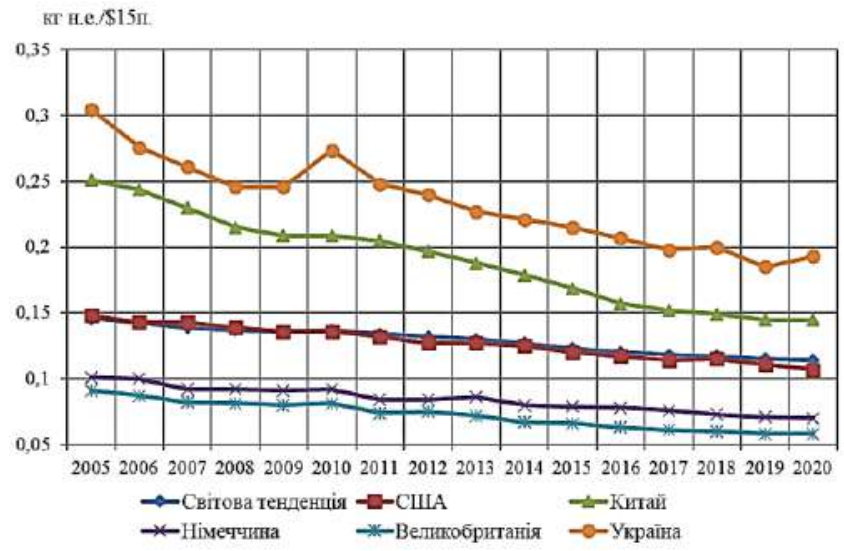

Рис. 2. Динаміка енергосмності економік країн світу

Високий показник енергоємності ВВП в країнах Близького Сходу, в Росії, Китаї та ряді азіатських країн (Тайвань, Південна Корея) пояснюється переважанням енергоємних галузей, спрямованістю економіки на експорт ресурсів і низькими цінами на енергію (відсутні стимули підвищувати енергоефективність) [8].

Процеси декарбонізації виробництва передбачають використання енергетичних ресурсів 3 низькими обсягами викидів $\mathrm{CO}_{2}$ протягом всього життєвого циклу. Порівняння емісії вуглекислого газу при використанні різних первинних 
Сучасна траєкторія розвитку науково-технічного прогресу в Україні та світі

енергоресурсів для вироблення електроенергії і для опалення наведені в табл. 2.

Таблиця 2

Викиди вуглекислого газу при використанні різних енергетичних ресурсів [9]

\begin{tabular}{|c|c|}
\hline Енергетичний ресурс & $\begin{array}{c}\text { Обсяг } \\
\text { викидів Со2, } \\
\text { г/кВт·год }\end{array}$ \\
\hline Буре вугілля (для виробництва електроенергії) & 1153 \\
\hline Кам'яне вугілля (для виробництва електроенергії) & 949 \\
\hline Буре вугілля (опалення) & 729 \\
\hline Кам'яне вугілля (опалення) & 622 \\
\hline Природний газ (для виробництва електроенергії) & 428 \\
\hline Біомасса & 409 \\
\hline Природний газ (для виробництва електроенергії & 148 \\
\hline та опалення) & 32 \\
\hline Атомна енергія (для виробництва електроенергії) & 27 \\
\hline Сонячна енергія (для виробництва електроенергії) & 24 \\
\hline Енергія вітру (для виробництва електроенергії) & \\
\hline
\end{tabular}

Найвищій показник за обсягами викидів протягом життєвого циклу на кВт·годину електроенергії, що виробляється паливом, становить для вугілля 1153 г $\mathrm{CO}_{2}$ і для газу 428 г $\mathrm{CO}_{2}$. На відміну від цього, сонячна фотоелектрична енергія виділяє 27 г $\mathrm{CO}_{2}$, а енергія вітру до 24 г $\mathrm{CO}_{2}$.

Існує дискусія про те, чи можна вважати природний газ «низьковуглецевим» енергетичним ресурсом. Незважаючи на те, що природний газ вважається більш екологічно чистим паливом в порівнянні 3 вугіллям i нафтою, при його спалюванні виділяється в 15 разів більше $\mathrm{CO}_{2}$, ніж при використанні сонячної енергії, і в 18 разів більше $\mathrm{CO}_{2}$, ніж виділяють вітряні електростанції. Тому, природний газ досить часто розглядають як «перехідне паливо» від вугілля до відновлюваних джерел енергії, оскільки його життєвий цикл викидів вуглекислого газу в два рази нижче, ніж у вугілля.

Існують суперечливі погляди і дослідження щодо реальних викидів парникових газів при використанні ядерної енергії протягом всього життєвого циклу. Так, Ітан Уорнер і Гарвін Хіт у своєму дослідженні виявили, що життєвий цикл ядерної енергетики коливається від 4 г до 220 г $\mathrm{CO}_{2} /$ кВт.год [10]. При 
цьому враховувалися всі фактори: починаючи з видобутку уранової руди, збагачення урану і закінчуючи поводженням 3 радіоактивними відходами. Тому, на нашу думку, атомна енергія не може розглядатись у якості джерела зеленої енергії, оскільки при її використанні існує небезпека аварій і радіоактивного забруднення, яке може охопити значні території і бути причиною негативних екологічних наслідків як для навколишнього середовища так і для здоров'я населення.

Таким чином, низьковуглецевий розвиток може бути досягнутий:

- за рахунок скорочення частки джерел енергії на основі викопного палива і збільшення обсягів використання джерел зеленої енергетики, тобто відновлювальних джерел енергії;

- а рахунок зниження попиту на енергію, засновану на джерелах викопного палива, за допомогою заходів і напрямків політики з енергоефективності.

Зелена енергетика є одним з ключових елементів низьковуглецевого розвитку. Конкурентоздатність відновлюваної енергетики істотно збільшується останні роки. Незважаючи на кризу, спричинену COVID-19, відновлювана енергія на чолі 3 вітровою та сонячною енергією продовжувала активно зростати. Примітно, що вітрові та сонячні потужності у 2020 році зросли на колосальні 260 ГВт, що на 50\% більше, ніж будь-який попередній період і більш ніж у чотири рази перевищує потужність з інших джерел (рис. 3, рис. 4).

За останні роки в країнах світу щорічно до електромережі додавалося більше відновлюваних джерел енергії, ніж викопного палива та ядерної енергії разом узятих. Технології відновлюваної енергії зараз домінують на світовому ринку нових виробничих потужностей, оскільки вони стали більш дешевими джерелами електроенергії на багатьох ринках [11]. Це сприяє активним процесам декарбонізації енергетичного сектору. 


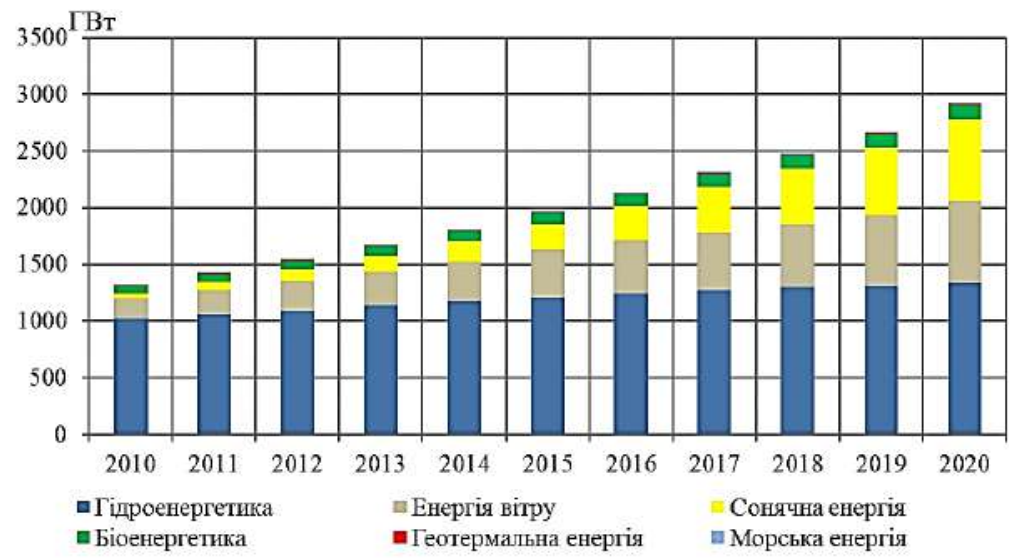

Рис. 3. Динаміка встановлених потужностей відновлювальних джерел енергії у світі, ГВт

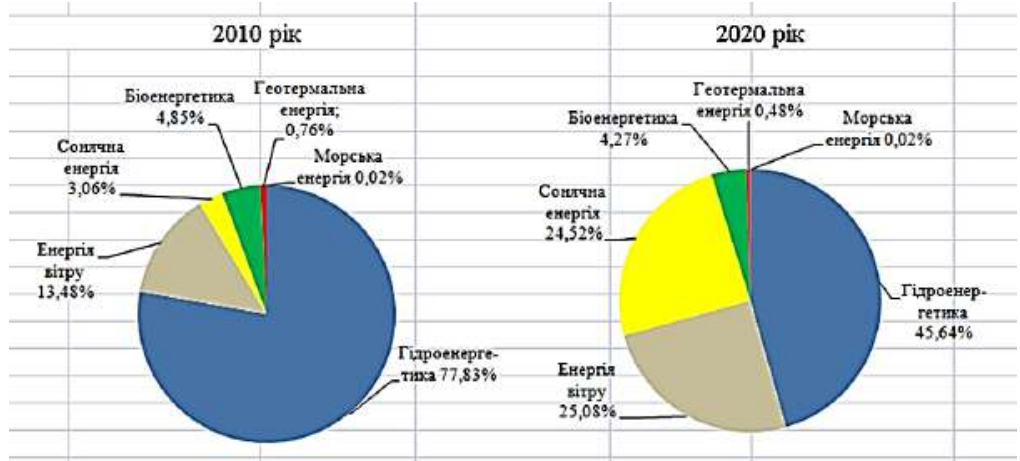

\section{Рис. 4. Порівняння питомої ваги видів відновлювальних джерел енергії за 2010 і 2020 роки}

У 2020 р. вироблення електроенергії з відновлюваних ресурсів (в тому числі гідроенергії) збільшилася більш ніж на 6\% завдяки постійному зростанню виробництва вітрової та сонячної енергії, а частка гідроенергії в світовому енергетичному балансі з 2000 p. стабільно становить близько 16\%. Таким активним темпам в галузі вироблення електроенергії з відновлюваних ресурсів в $€$, США, Китаї, Індії, Японії, Чилі та Австралії сприяли масштабні 
програми по боротьбі зі змінами клімату і зниження вартості технологій в вітровій і сонячній енергетиці [12]. Сприятливі гідрологічні умови також привели до збільшення вироблення електроенергії з поновлюваних джерел в Китаї, Європі (особливо в Швеції і Норвегії), Бразилії і Японії. На частку відновлюваних джерел енергії сьогодні припадає 38\% енергетичного балансу в ЄС, 28\% в Китаї, 23\% в Індії і 20\% в США та Японії (рис. 5).

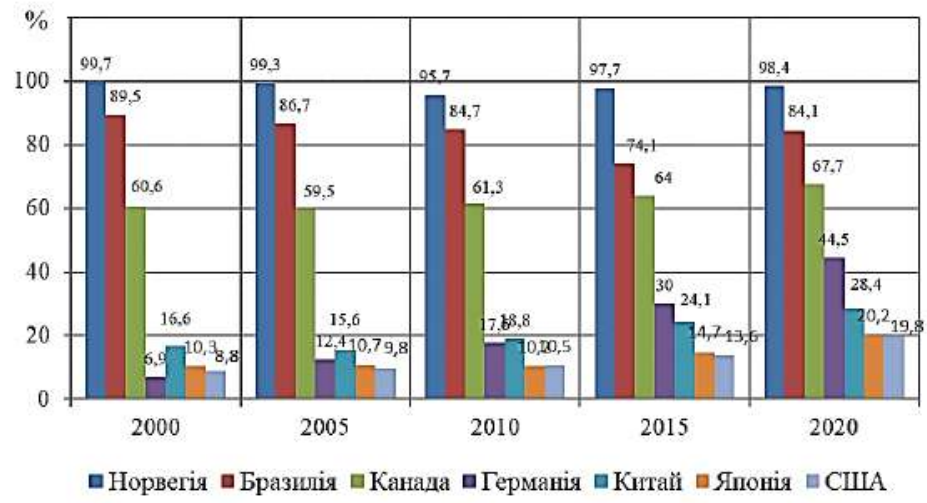

Рис. 5. Частка відновлюваних джерел енергії у виробництві електроенергії в деяких країнах світу у 2020 році [12]

Країни ЄС висувають все більш високі вимоги до стандартів екологічної безпеки, їх зусилля спрямовані на пошук альтернативи традиційному викопному паливу. Залежність від імпорту енергоносіїв, високі ціни на них, політичний фактор, кліматичні зміни стимулюють використання альтернативних видів палива. Питома вага відновлюваних джерел енергії значно зросла і сформувала $38 \%$ європейського електроенергії у 2020 році (порівняно з 34,6\% у 2019 році), вперше випередивши виробництво газу, яке впало до $37 \%$. Це важлива віха на шляху переходу Європи до зеленої енергетики та низьковуглецевого розвитку. На рівні окремих країн Німеччина та Іспанія (та окремо Велика Британія) також вперше досягли цієї мети.

Активне використання вітрової і сонячної енергії сприяє розвитку зеленої енергетики в Європі. Вітрогенерація зросла на $9 \%$ у 2020 році, а сонячна - на 15\%, що разом складає п'яту частину електроенергії Європи. 32015 р. вітрова та сонячна енергія 
Сучасна траєкторія розвитку науково-технічного прогресу в Україні та світі

забезпечують зростання відновлюваних джерелах енергії в Європі, оскільки розвиток біоенергетики призупинився, а виробництво гідроенергії залишається незмінним (рис. 6).

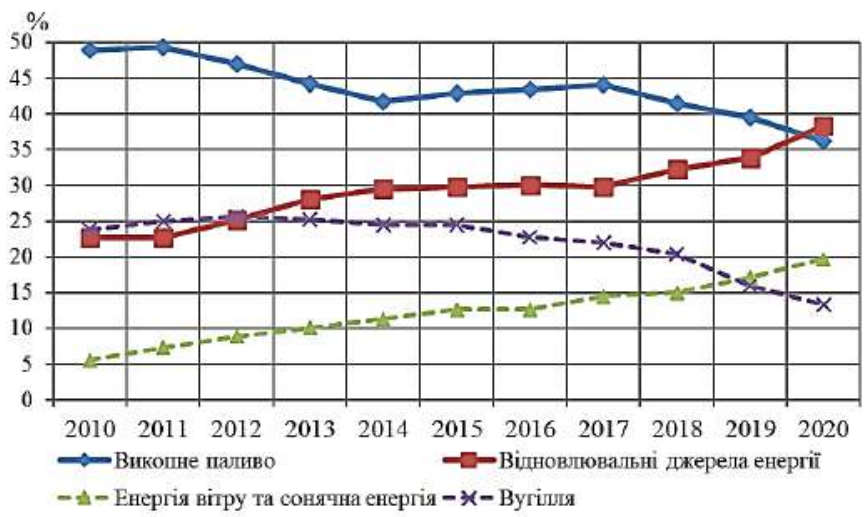

\section{Рис. 6. Динаміка питомої ваги різних видів первинної енергії в виробництві електроенергії в ЄС-27 [13]}

Виробництво вугілля скоротилося на $20 \%$ у 2020 р. і зменшилося вдвічі з 2015 р. Незважаючи на пандемію, видобуток газу в 2020 р. впав лише на $4 \%$. Атомна енергетика знизила свої потужності на $10 \%$ у 2020 р., що $є$ найбільшим падінням за багато років.

Це означає, що електроенергія в Європі в 2020 р. була на $29 \%$ чистішою, ніж у 2015 р. Вуглецева інтенсивність знизилася 3 317 грамів $\mathrm{CO}_{2}$ за кіловат-годину в 2015 р. до 226 грамів у 2020 р. Хоча за цей час видобуток вугілля скоротився, зниження компенсувалося збільшенням видобутку газу, що сповільнювало зменшення вуглецеємності енергетичного сектору.

Країни-лідери Європи у використанні енергії вітру та сонячної енергії - це Данія (61 \% вироблених потужностей за рік), Ірландія (35\%), Німеччина (33 \%) и Іспанія (29 \%). Тоді як деякі країни продовжують відставати, незважаючи на чудові сонячні та вітрові умови. В цих країнах майже не спостерігалося зростання потужностей зеленої енергетики з 2015 року - це Португалія, Румунія, Австрія, Італія, Чехія, Словаччина та Болгарія.

Що стосується Німеччини, то хоча ця країна і володіє значними потужностями відновлюваних джерелах енергії, ії̈ електроенергія все ще залишається набагато бруднішою за середній показник у ЄС через відносно високу частку використання вугілля [13]. 
Сучасна траєкторія розвитку науково-технічного прогресу в Україні та світі

Енергетичний сектор, відомий своїми повільними темпами змін, зараз переживає динамічний перехід. Навіть в умовах потрясінь, спричинених пандемією COVID-19, системи на основі відновлюваних джерел енергії продемонстрували надзвичайну стійкість і технічну надійність

Наразі низьковуглецевий розвиток став пріоритетом в політичних програмах багатьох країн світу. У грудні 2019 р. Європейська комісія розробила «Європейський зелений курс» (European Green Deal) - в основі якого передбачається досягнення «вуглецевої нейтральності» до 2050 року (скільки емітували $\mathrm{CO}_{2}$, стільки і поглинули) i забезпечення стійкості економіки ЄС. В документі зазначено, що подальша декарбонізація енергетичної системи має вирішальне значення для досягнення кліматичних цілей у 2030 та 2050 роках. Виробництво та використання енергії у різних секторах економіки становлять понад $75 \%$ викидів парникових газів $€ С$. Енергоефективність повинна бути у пріоритеті. Необхідність розвитку енергетичного сектору, який базуватиметься переважно на відновлюваних джерелах, доповнюючись швидким припиненням видобутку вугілля та декарбонізації газу. Водночас енергопостачання $€ \mathrm{C}$ має бути безпечним і доступним для споживачів та бізнесу. Для того, щоб це сталося, важливо забезпечити повну інтеграцію європейського енергетичного ринку, дотримуючись технологічного нейтралітету [14].

Згідно розробленого «Європейського зеленого курсу» передбачається підвищення частки відновлюваних джерел енергії в енергобалансі до 38-40\% (в електроенергії - до 65\%). При цьому до 2030 р. ЄС передбачає скоротити споживання вугілля на $70 \%$, а нафти і газу - на 30 і 25\% в порівнянні з 2015 р. На реалізацію поставлених цілей заплановано держане фінансування в розмірі 1 трлн євро на найближчі 10 років.

Одна 3 ключових вимог Паризької угоди зі змін клімату передбачає розробку i реалізацію національних стратегій довгострокового розвитку з низьким рівнем викидів парникових газів для зниження ризиків кліматичних змін для населення i економіки [15]. За даними ООН більще ніж 14 країн світу і ЄC-27 розробили стратегії довгострокового низьковуглецевого розвитку. Стратегія США передбачає зниження викидів парникових газів на $80 \%$ або більше до 2050 (від рівня 2005 року), Японії - на 80\% до 2050 року від рівня 1990 року, а мета Європейського Союзу вуглецева нейтральность до 2050 року (табл. 3). 
Наразі національні енергетичні та кліматичні плани складають лише близько 72 ТВт•год нових генерацій вітрової та сонячної енергії на рік, а не 100 ТВт.год/рік, які необхідні для низьковуглецевого розвитку. Перехід від вугілля до зеленої енергії все ще занадто повільний, щоб досягти 55\% скорочення викидів парникових газів до 2030 року та кліматичної нейтральності до 2050 року. Очевидно, що країнам $€ C$ необхідно значно посилити свої зобов'язання що боротьби зі зміною клімату до 2030 року [16].

Розумна інтеграція відновлюваних джерел енергії, енергоефективності та інших стійких рішень у різних секторах допоможе досягти декарбонізації за найменші можливі витрати. Паралельно буде сприяти декарбонізації газового сектору, в тому числі шляхом посилення підтримки розробки декарбонізованих газів, за допомогою перспективного планування конкурентоспроможного ринку декарбонізованого газу та вирішення проблеми викидів метану, пов'язаного з енергоспоживанням.

Таблиця 3

Заявлені цілі країн світу у досягненні низьковуглецевого розвитку $[17 ; 18 ; 19]$

\begin{tabular}{|c|c|c|}
\hline Країна & Ціль до 2030 р. & Ціль до 2050 р. \\
\hline Китай & $\begin{array}{c}\text { Скорочення вуглецеємності ВВП } \\
\text { на } 60-65 \% \text { від рівня } 2005 \text { р. }\end{array}$ & $\begin{array}{c}\text { Довгострокова стратегія } \\
\text { відсутня }\end{array}$ \\
\hline США & $\begin{array}{c}\text { Скорочення викидів } \\
\text { парникових газів на } 26-28 \text { \% до } \\
2025 \text { р. від рівня } 2005 \text { р. }\end{array}$ & $\begin{array}{c}\text { Скорочення викидів } \\
\text { парнікових газів на } 80 \% \text { від } \\
\text { рівня } 2005 \text { р. }\end{array}$ \\
\hline Індія & $\begin{array}{c}\text { Скорочення вуглецеємності ВВП } \\
\text { на 33-35 \% від рівня } 2005 \text { р. }\end{array}$ & $\begin{array}{c}\text { Довгострокова стратегія } \\
\text { відсутня } \\
\end{array}$ \\
\hline Японія & $\begin{array}{c}\text { Скорочення викидів } \\
\text { парникових газів на } 25 \text { \% від } \\
\text { рівня } 2005 \text { р. }\end{array}$ & $\begin{array}{c}\text { Скорочення викидів } \\
\text { парникових газів на } 80 \% \text { до } \\
2050 \text { р. від рівня } 2013 \text { р. }\end{array}$ \\
\hline $\begin{array}{l}\text { Південна } \\
\text { Корея }\end{array}$ & $\begin{array}{c}\text { Скорочення викидів } \\
\text { парникових газів на } 37 \text { \% до } \\
2030 \text { р. за сценарієм } \\
\text { мінімальних витрат BAU } \\
\text { («Business as Usual») } \\
\end{array}$ & $\begin{array}{c}\text { Скорочення викидів } \\
\text { парникових газів до рівня } \\
396 \text { млн т } \mathrm{CO}_{2} \text {-екв. }\end{array}$ \\
\hline Канада & $\begin{array}{c}\text { Скорочення викидів } \\
\text { парникових газів на } 30 \% \text { до } \\
2030 \text { р. від рівня } 2005 \text { р. }\end{array}$ & $\begin{array}{c}\text { Скорочення викидів } \\
\text { парникових газів на } 80 \% \text { до } \\
2050 \text { р. від рівня } 2005 \text { р. }\end{array}$ \\
\hline Германія & $\begin{array}{c}\text { Скорочення викидів } \\
\text { парникових газів на } 55 \text { \% до } \\
2030 \text { р. від рівня } 1990 \text { р. } \\
\end{array}$ & $\begin{array}{c}\text { Скорочення викидів } \\
\text { парникових газів на } 80-95 \% \\
\text { до } 2050 \text { р. від рівня } 1990 \text { р. }\end{array}$ \\
\hline Країни ЄС-27 & $\begin{array}{c}\text { Скорочення викидів } \\
\text { парникових газів на } 40 \% \text { до } \\
2030 \text { р. від рівня } 1990 \text { р. }\end{array}$ & $\begin{array}{l}\text { Досягнення вуглецевої } \\
\text { нейтральності. }\end{array}$ \\
\hline
\end{tabular}


Сучасна траєкторія розвитку науково-технічного прогресу в Україні та світі

Перехід до кліматичної нейтральності також потребує відповідної інфраструктури. Посилення транскордонного та регіонального співробітництва допоможе досягти переваг переходу на низьковуглецеву енергію за доступними цінами. В пріоритеті розвиток інноваційних технологій і формування інфраструктури на базі розумних електромереж, збирання, зберігання та використання вуглецю, зберігання енергії [20].

На думку багатьох дослідників, розвиток глобальної енергетичної системи увійшов в новий етап фундаментальної трансформації. Такі зміни прийнято називати «Енергетичним переходом» (Energy Transition), однак уявлення про швидкість i глибину цього процесу значноо відрізняються.

Важливим чинником енергетичного переходу вважається технічний прогрес і поява абсолютно нових технологічних рішень, які здатні значно підвищити ефективність енергетичного сектора і змінити традиційний спосіб його функціонування. Таким чином світова економіка вступає в етап 4-го енергетичного переходу, пов'язаного з широким використанням відновлюваних джерел енергії та витісненням викопних видів палива.

Термін «енергетичний перехід» був запропонований канадським вченим Вацлавом Смілом і використовується «для опису зміни структури первинного енергоспоживання і поступового переходу від існуючої схеми енергозабезпечення до нового стану енергетичної системи» [21]. Розподіл енергетичних переходів, запропонований В.Смілом наведено нижче (табл. 4; рис. 7).

Енергетичний перехід - це радикальний зсув енергетичної системи від існуючої моделі до нової парадигми. Це досить складний процес і він виходить за рамки лише заміни одного джерела енергії іншим. На думку британського професора Бенджаміна Совакула, енергетичний перехід включає зміни в трьох взаємопов'язаних вимірах [25]:

- матеріальні елементи енергетичної системи, які включають технології, інфраструктуру, ринок, виробниче обладнання, моделі споживання та ланцюги розподілу енергетичних ресурсів;

- нові стратегії та моделі інвестування, зміна виробників енергії, зміна поведінки бізнесу;

- соціально-технічні режими, які містять офіційні правила, стандарти та політику, а також систему мислення та переконань. 
Характеристика енергетичних перходів у зміні структури первинного енергоспоживання [22]

\begin{tabular}{|c|c|}
\hline Енергетичний перехід & Характеристика \\
\hline $\begin{array}{c}\text { Перший енергетичний } \\
\text { перехід }\end{array}$ & $\begin{array}{c}\text { Перехід від використання біомаси до } \\
\text { вугілля. Частка вугілля в загальному } \\
\text { обсязі споживання первинної енергії з } \\
1840 \text { по } 1900 \text { роки збільшилася з } 5 \% \text { до } \\
50 \% \text { Вугілля стало основним джерелом } \\
\text { енергії індустріального світу } \\
\end{array}$ \\
\hline $\begin{array}{c}\text { Другий енергетичний } \\
\text { перехід }\end{array}$ & $\begin{array}{c}\text { Активний видобуток і поширення } \\
\text { використання нафти. Частка нафти і } \\
\text { нафтопродуктів в первинному } \\
\text { енергоспоживанні зросла з 3\% в } 1915 \text { р. } \\
\text { до 45\% у } 1975 \text { р. Найбільш інтенсивний } \\
\text { період переходу з вугілля на нафту } \\
\text { припав на роки після Другої світової } \\
\text { війни. Почалося «століття моторів» і } \\
\text { переважання нафти. Період завершився } \\
\text { в кінці 1970-х років нафтовою кризою. }\end{array}$ \\
\hline $\begin{array}{c}\text { Третій енергетичний } \\
\text { перехід }\end{array}$ & $\begin{array}{c}\text { Активне використання природного } \\
\text { газу. Його частка в первинному } \\
\text { енергоспоживанні зросла з 3\% в } 1930 \text { р. } \\
\text { до } 23 \% \text { в } 2017 \text { р. за рахунок часткового } \\
\text { витіснення як вугілля, так і нафти. }\end{array}$ \\
\hline $\begin{array}{c}\text { Четвертий енергетичний } \\
\text { перехід }\end{array}$ & $\begin{array}{c}\text { Останні роки відбувається початок } \\
\text { четвертого енергетичного переходу. } \\
\text { Відбувається активний розвиток } \\
\text { широкого спектру відновлюваних } \\
\text { енергетичних ресурсів і технологій: } \\
\text { вітрові електростанції, сонячні батареї, } \\
\text { використання біомаси та відходів } \\
\text { споживання і виробництва. Частка } \\
\text { відновлюваних джерел енергії (без } \\
\text { урахування гідроенергії) в світовому } \\
\text { загальному обсязі споживання } \\
\text { первинної енергії стрімко зростає } \\
\end{array}$ \\
\hline
\end{tabular}

Державна енергетична політика відіграє важливу роль у трансформації енергетичної системи. Шляхом застосування фіскальних інструментів (податків, субсидій), формування галузевих стандартів відносно палива і транспортних засобів, а також за допомогою специфічних регулятивних заходів уряд 
здатний істотно стимулювати або, навпаки, дестимулювати споживання того чи іншого виду палива і управляти попитом на енергоносії. При цьому найчастіше механізми державної підтримки виявляються настільки потужним драйвером для зміни енергобалансу, що переважують об'єктивні економічні показники [26].

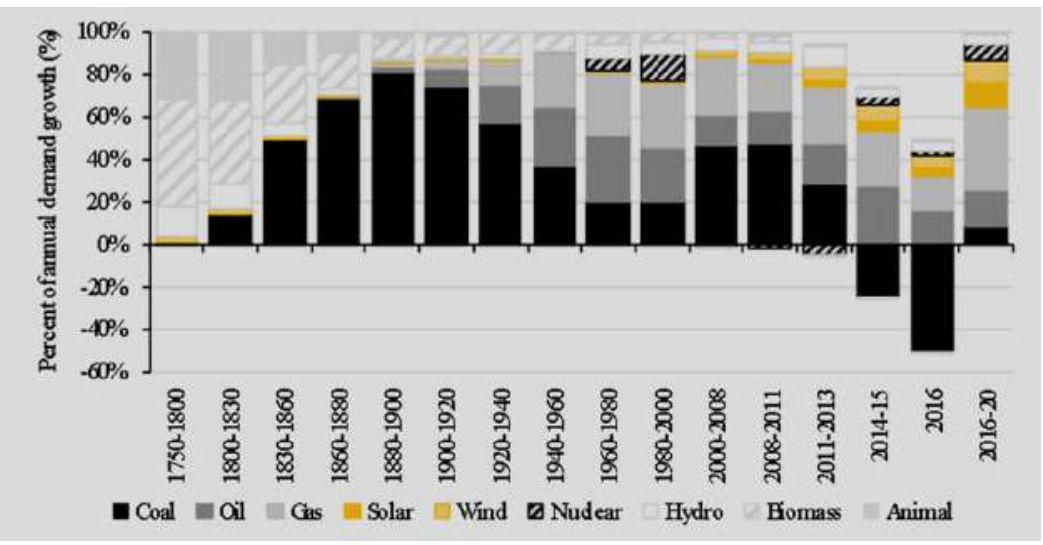

Рис. 7. Глобальна енергія та первинны енергетичні ресурси [23; 24]

На етапі четвертого енергетичного переходу, на відміну від попередніх трьох, основним спонукальним чинником стає не економічна привабливість нових джерел енергії, а декарбонізація виробництва і боротьба з глобальною зміною клімату (табл.5).

Безперечним $\epsilon$ прагнення урядів всіх країн забезпечити конкурентоспроможність національних економік і прискорити їх зростання за рахунок універсального доступу до енергії, а також прагнення підвищити енергетичну безпеку, знижуючи залежність від імпорту вуглеводнів і нарощувати поставки від місцевих ефективних низьковуглецевих джерел енергії.

3 боку суспільства до паливно-енергетичних ресурсів висуваються вимоги: доступність енергії в достатніх обсягах і за прийнятними цінами; надійність i безпека енергопостачання; екологічність, тобто мінімізації антропогенного впливу енергосистем на навколишнє середовище і здоров'я населення. 
Таблиця 5

Державні інструменти енергетичної політики в напрямку низьковуглецевого розвитку і боротьби зі зміною клімату

\begin{tabular}{|c|c|c|}
\hline \multicolumn{2}{|c|}{ Інструменти } & Пояснення \\
\hline \multirow{3}{*}{ Економічні } & Податки & $\begin{array}{l}\text { Податок на вуглець (стосовно } \\
\text { виробництва електроенергії або } \\
\text { палива). }\end{array}$ \\
\hline & $\begin{array}{c}\text { Продаж дозволів на } \\
\text { допустимий обсяг } \\
\text { викидів }\end{array}$ & $\begin{array}{l}\text { - Торгівля викидами парникових газів. } \\
\text { - Кредити на викиди в рамках } \\
\text { механізму } \\
\text { - чистого розвитку (Clean Development } \\
\text { Месhanism, CDM), який визначений у } \\
\text { Кіотському протоколі. } \\
\text { - Продаж зелених сертифікатів. }\end{array}$ \\
\hline & Субсидії & $\begin{array}{l}\text { - Відмова від субсидій на викопне } \\
\text { паливо. } \\
\text { - Пільгові тарифи для стимулювання } \\
\text { розвитку відновлюваних джерел } \\
\text { енергії. }\end{array}$ \\
\hline $\begin{array}{c}\text { Нормативно- } \\
\text { правові }\end{array}$ & $\begin{array}{c}\text { Підходи до } \\
\text { регулювання } \\
\text { діяльності у } \\
\text { секторі енергетики }\end{array}$ & $\begin{array}{l}\text { - Стандарти енергоефективності, } \\
\text { енергетичного та екологічного } \\
\text { менеджменту. } \\
\text { - Стандартизований портфель } \\
\text { відновлюваних джерел енергї. } \\
\text { - Рівний доступ до електромережі. } \\
\text { - Правовий статус довгострокового } \\
\text { зберігання } \mathrm{CO}_{2} \text {. }\end{array}$ \\
\hline Соціальні & $\begin{array}{c}\text { Надання державою } \\
\text { суспільних благ та } \\
\text { послуг }\end{array}$ & $\begin{array}{l}\text { - Наукові дослідження і інноваційні } \\
\text { розробки } \\
\text { - Розширення інфраструктури сектора } \\
\text { зеленої енергетики (автономні } \\
\text { котельні, розвиток громадського } \\
\text { лектротранспорту тощо) } \\
\text { - Інвестиції в інфраструктуру } \\
\text { транспорту на базі альтернативного } \\
\text { палива; } \\
\text { - Підготовка кадрів і формування } \\
\text { екологічної свідомості населення. }\end{array}$ \\
\hline Інформаційні & $\begin{array}{c}\text { Інформаційні } \\
\text { програми }\end{array}$ & $\begin{array}{l}\text { - Енергетичний аудит. } \\
\text { - Програми консультування з питань } \\
\text { енергетики. } \\
\text { - Аналіз статистичних даних. }\end{array}$ \\
\hline
\end{tabular}

Важливо і те, що в різних секторах економіки декарбонізація стає ключовим параметром конкурентоспроможності. Глобальні кліматичні проблеми стимулюють компанії брати на себе зобов'язання щодо повного переходу на відновлювані джерела енергії, інвестори по всьому світу відмовляються від 
Сучасна траєкторія розвитку науково-технічного прогресу в Україні та світі

фінансування секторів, пов'язаних з високими викидами $\mathrm{CO}_{2} \mathrm{i}$ інших шкідливих речовин.

Таким чином, зелена енергетика та енергоефективність $\epsilon$ ключовими елементами успішного енергетичного переходу та низковуглецевого економічного розвитку. Але інтеграція енергетичних технологій декарбонізації в світову енергетичну систему як 3 технічної, так і з ринкової точки зору містить певні складності.

Сучасний перехід світового енергетичного сектору потребуватиме значних інвестицій. Кліматична політика вимагатиме збільшення масштабу інвестицій щодо технологічного переоснащення енергосистеми до 3,8 трильйонів доларів США на рік у всьому світі в середньому за період 2020-2050 роки [27].

Енергетичний перехід буде надзвичайно складним, так як потрібно вирішувати ряд політичних, економічних та технічних проблем та викликів. В реальних умовах, дуже важко передбачити розвиток процесу енергетичного переходу, оскільки при цьому відбувається взаємодія інституцій, технологічних рішень, бізнесу і суспільства.

\section{2. Пріоритети переходу до низьковуглецевого розвитку енергетичного сектору в Україні}

Експертами всього світу оцінюються ризики, пов'язані 3 глобальною зміною клімату, його політичні, соціальноекономічні, демографічні наслідки.

Згідно досліджень українських вчених, основними негативними наслідками зміни клімату в Україні є: підвищення ризиків для здоров'я людини, пов'язаних практично з усіма проявами гідрометеорологічних явищ; значне зменшення врожаїв основних сільськогосподарських культур; загострення проблем з водопостачанням вже не тільки південних і південносхідних регіонів; посилення деградації земель та опустелювання; зменшення продуктивності, життєздатності та стійкості лісів; пришвидшення деградації екосистем; виникнення аварій i нестабільного функціонування електричних мереж та централізованих систем теплопостачання, інших об'єктів інфраструктури та багато іншого [28].

У липні 2016 року Україна ратифікувала Паризьку угоду про зміну клімату і відповідно взяла на себе зобов'язання утримати підвищення середньої температури в межах $2^{\circ} \mathrm{C}$, а також поряд 3 
Сучасна траєкторія розвитку науково-технічного прогресу в Україні та світі

іншими країнами була покликана розробити довгострокову стратегію низьковуглецевого розвитку.

Низьковуглецевий розвиток має стати основною моделлю національної економіки та сприяти економічному та соціальному розвитку нашої країни. Тому у грудні 2016 року Кабінетом Мінстрів України була схвалена «Концепція реалізації державної політики у сфері зміни клімату на період до 2030 року». Метою Концепції $\epsilon$ вдосконалення державної політики у сфері зміни клімату для досягнення сталого розвитку держави, створення правових та інституційних передумов для забезпечення поступового переходу до низьковуглецевого розвитку за умови економічної, енергетичної та екологічної безпеки і підвищення добробуту громадян. Одним з результатів Концепції передбачено забезпечення дотримання усіх зобов'язань України за Рамковою конвенцією ООН про зміну клімату та іншими міжнародними угодами у сфері зміни клімату і забезпечення досягнення у 2030 році очікуваного національно визначеного внеску, який не перевищуватиме $60 \%$ рівня базового 1990 року (тобто зниження викидів парникових газів на 40\% до 2030 року) [29].

У липні 2021 року Кабінетом Міністрів України було схвалено Оновлений (другий) національно визначений внесок України в Паризьку угоду, відповідно до якого викиди парникових газів мають скоротитися на 65\% до 2030 року від рівня 1990 року [30]. Досягнення кліматичної нейтральності передбачено в Україні не пізніше 2060 року, як це визначено в «Енергетичній стратегії України на період до 2035 року» [31].

Показник скорочення викидів на $65 \%$ до 2030 р. було отримано з огляду на розрахунок, що в 1990 р. викиди оксиду вуглецю в України 3 урахуванням землекористування та лісівництва становили 884 млн тонн. При цьому в 2019 р., згідно з кадастром, викиди $\mathrm{CO}_{2}$ становили 332 млн тонн - 37,6\% від рівня 1990 року.

У липні 2018 року була затверджена Кабінетом міністрів України «Стратегія низьковуглецевого розвитку України до 2050 року» у ії фокусі знаходиться розгляд і оцінка різних сценаріїв низьковуглецевого розвитку і визначення політик і заходів переходу економіки України до моделі економічного зростання, що поєднується зі зниженням викидів парникових газів (рис. 8) .

Важливими рисами такого економічного зростання є: низькі вуглецеві викиди; ефективне використання природних ресурсів; збереження, збільшення і відновлення природного капіталу; 
Сучасна траєкторія розвитку науково-технічного прогресу в Україні та світі

запобігання втрати біорізноманіття та екосистемних послуг; зростання доходів і зайнятості.

Таким чином, в Україні прийнято ряд законодавчонормативних актів в енергетичній сфері, які відповідають вимогам Паризької угоди про зміну клімату та Кіотського протоколу. Політики і заходи за даними нормативними актами відповідають дотриманню обмежень по викидах парникових газів і стали основої при проведенні в країні роботи зі скорочення питомого споживання вуглеводневого палива і підвищення енергоефективності економіки.

Україна виробляє близько двох третин необхідних енергоресурсів самостійно, проте, при цьому, для задоволення внутрішнього попиту вона продовжує імпортувати газ, неочищену нафту та нафтопродукти [33]. В останні роки відбувається зниження обсягів виробництва енергії. Загальне постачання первинної енергії в Україні у 2019 році дорівнювало 89072 тис. т н.е., що 32, 8 \% менше ніж у 2010 році (рис. 9).

За даними Державної служби статистики України у структурі загального постачанні первинної енергії у 2019 р. перше місце займає вугілля і торф (28,9 \%), за ними слідує природний газ (26,3\%), третє місце належить атомній енергії $(24,4 \%)$, четверте - нафті і нафтопродуктам (15,3\%). Відовідно частка викопного паливо у складі первинної енергії у 2019 р. складає - 70,5 \%. За десять років (2010-2019 рр.) знизилася питома вага природного газу на 15,5 в.п. і збільшилася частка відновлюваних джерел енергії 32 \% (3 гідроенергією) у 2010 році до 4,9 \% у 2019 році, в основному за рахунок використання біопалива та відходів (рис. 10).

При цьому відбувається нарощування потужностей сонячних та вітрових електростанцій. Обсяг виробництва сонячної енергії у 20182019 роках збільшився з 948,2 до 2 640,4 МВт та обсяг виробництва вітрової енергії - з 515,4 до 776,4 МВт відповідно [34]. 


\section{Стратегія низьковуглецевого розвитку України до 2050 року}

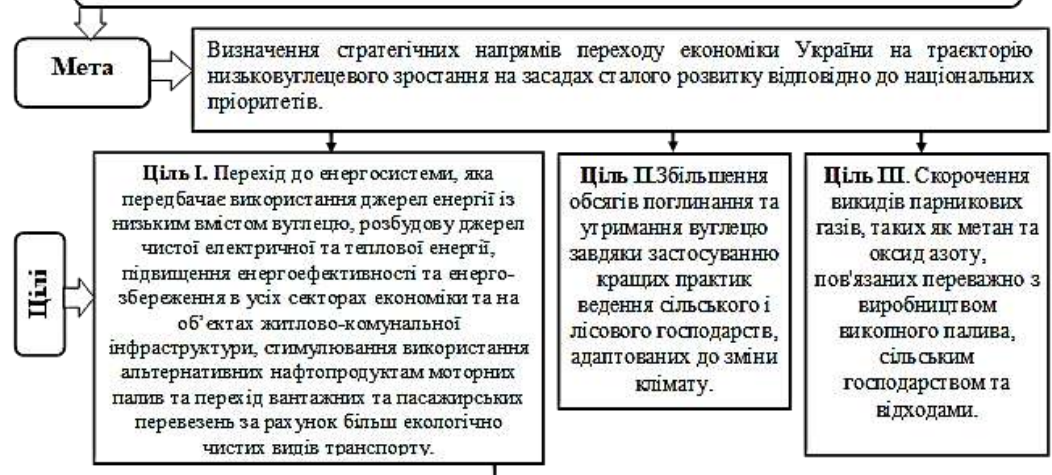

\begin{tabular}{|c|c|}
\hline \multicolumn{2}{|c|}{ Декарбонізація енергетики України } \\
\hline 7 & \\
\hline 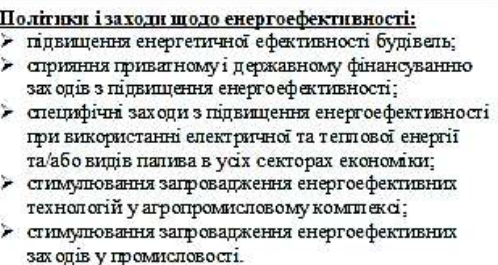 & 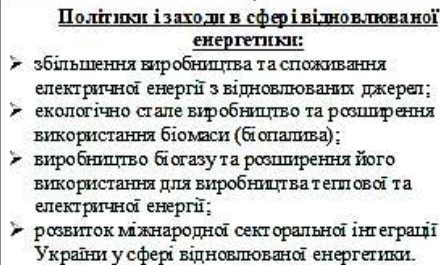 \\
\hline
\end{tabular}

\begin{tabular}{|c|c|}
\hline 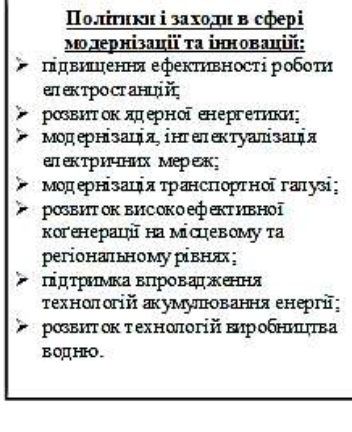 & 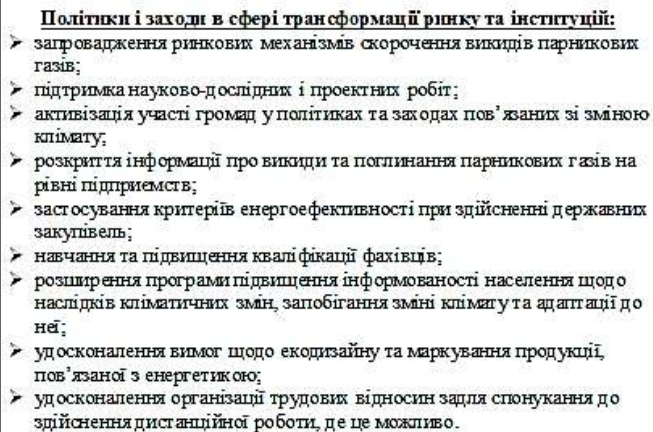 \\
\hline
\end{tabular}

\section{Рис. 8. Цілі, політики і заходи Стратегії низько вуглецевого розвитку України до 2050 року [32]}


тис. тонн н.е.

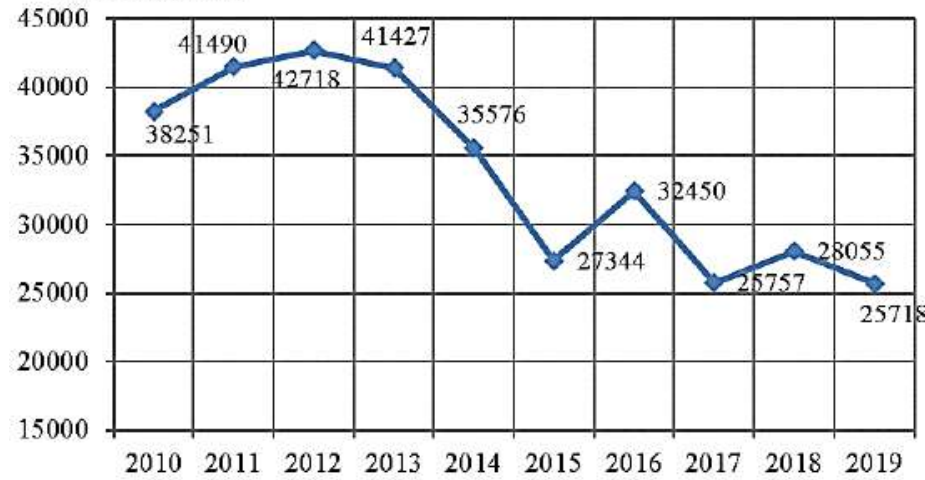

\section{Рис. 9. Динаміка загального постачання первинної енергії в Україні за період 2010-2019 роки}

Одним 3 важливих інструментів переходу до низьковуглецевого розвитку $є$ регулювання викидів парникових газів в секторах економіки. Треба відзначити, що процес декарбонізації енергетичного сектору України відбувається, але потребує інтенсифікації. При цьому обсяг викидів вуглекислого газу в атмосферне повітря в 2020 р. склав 170 млн т $\mathrm{CO}_{2}$, це в 4 рази менше ніж даний показник у 1990 р. (690 млн т $\left.\mathrm{CO}_{2}\right)$. Таке скорочення, в основному, $є$ наслідком зменшення використання енергетичних ресурсів через спад ВВП, зниження чисельності населення та соціальних стандартів життя людей. Але протягом останніх років тенденція до зниження емісії вуглекислого газу $\epsilon$ досить незначна. Головним чином, викиди $\mathrm{CO}_{2} \epsilon$ результатом спалювання вугілля, газу та мазуту на електростанціях і в котельнях. Джерелами більшої частини викидів $\epsilon$ централізоване вироблення тепла та виробництво електроенергії (рис. 11).

Показники вуглецеємності ВВП (інтенсивності викидів $\mathrm{CO}_{2}$ ) і вуглецевого коефіцієнту (обсяги викидів CO2 на спожиту тонну нафтового еквівалента) також мають тенденцію до зниження. В першу чергу це пов'язано зі зниженням обсягів споживання енергії, особливо в період карантинних заходів під час пандемії і обмежень в транспортному секторі у 2020 році. (рис. 12). Але порівняно 3 вуглецеємністю i вуглецевим коефіцієнтом розвинених країн світу, де активно впроваджуються державна 
низьковуглецева енергетична політика, показники України досить високі. Так, у 2020 р. вуглецеємність секторів економіки України складала 0,379 кг $\mathrm{CO}_{2} / \$ 15$ п., що в 5,9 разів більше ніж у Швеції $(0,064)$ і в 2,7 рази більше ніж в середньому в країнах Європейського Союзу $(0,139)$. Вуглецевий коефіцієнт в Україні за 2020 р. складає 1,96 т СО 2 / т н.е., що в 2,8 рази ніж в Швеції $(0,69)$ і в 1,3 рази більше ніж в Германії.

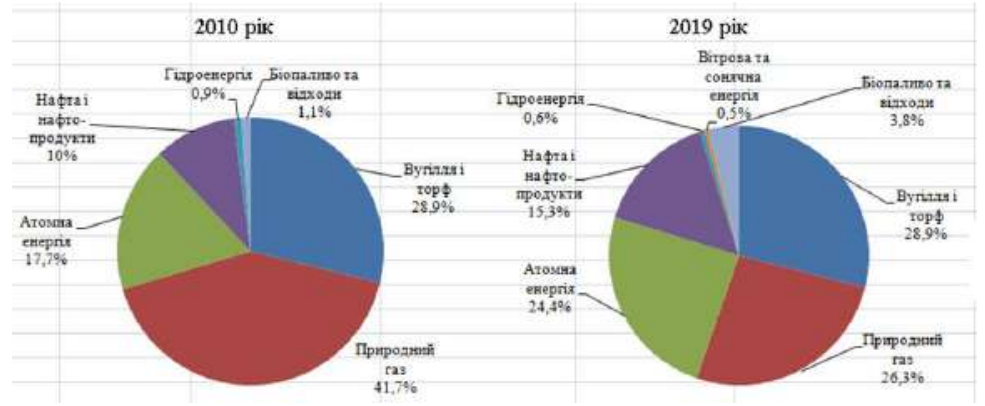

Рис. 10. Порівняння структури загального постачання первинної енергії в Україні у 2010 та 2019 роках

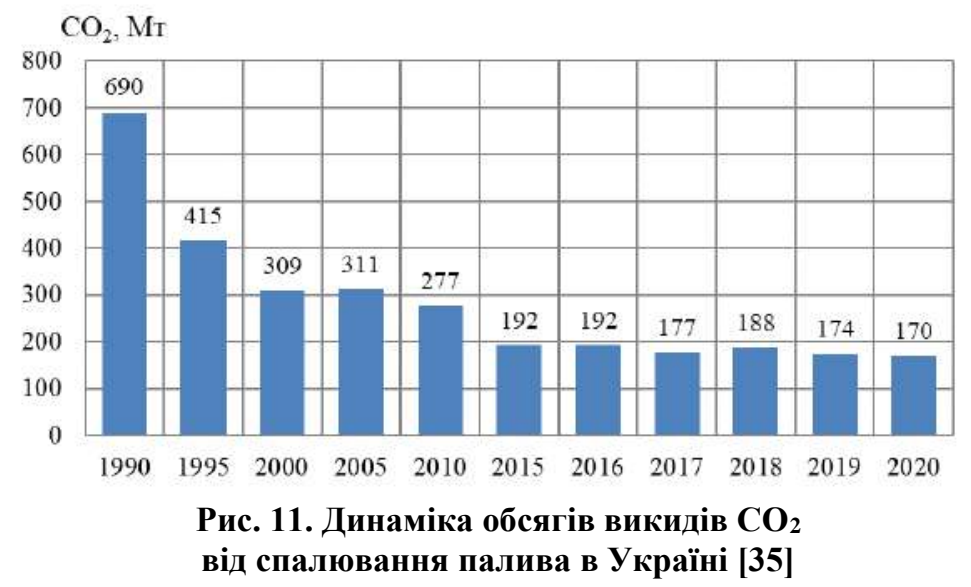

У порівнянні 3 розвиненми країнами світу в Україні енергоємність ВВП має дуже високий показник. У 2020 році Україна 
знаходилася на восьмому місці серед країн 3 максимальним показником енергоємності. Інтенсивність використання енергії на одиницю ВВП (за постійним паритетом купівельної спроможності) України у 2020 році становила 0,193 кг н.е./\$15п., що в 1,7 рази більше ніж середній світовий показник і в 3,3 рази більше ніж енергоємність Великої Британії, яка має один з самих низьких показників (див. рис. 2). Наша країна знаходиться на 5-му місці серед країн з максимальною енергоємністю.

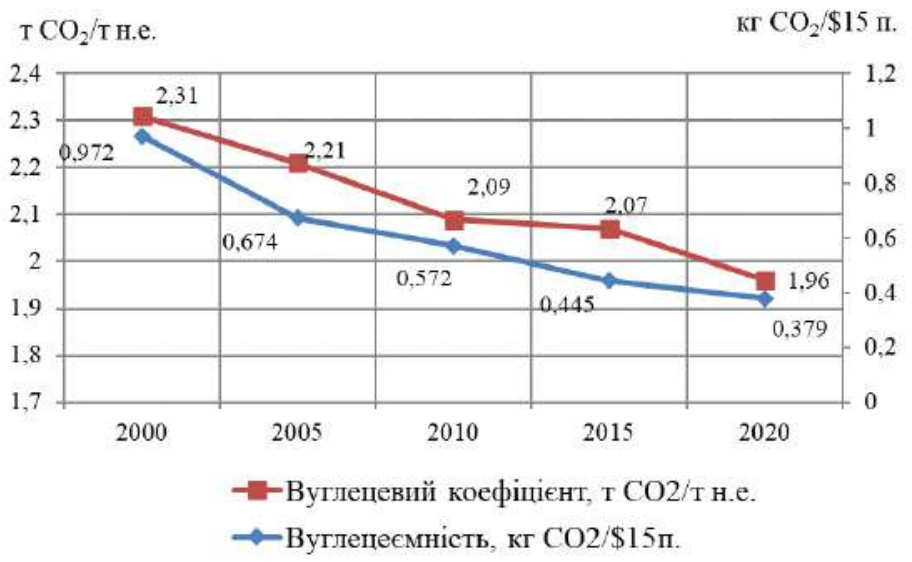

\section{Рис. 12. Динаміка зміни вуглецевого коефіціснта та вуглецесмності економіки України [36]}

Питання забезпечення енергетичної безпеки країни напряму пов'язані 3 екологічними і природоресурсними проблемами. Переважна більшість використовуваних енергетичних ресурсів в Україні відноситься до вичерпних. Встановлена потужність енергосистеми України складає станом на кінець 2020 p. 54 365,30 МВт. Більше половини встановленої енергетичної потужності вироблено на теплових електростанціях і теплових теплоцентралях (51,34 \%), які працюють переважно на викопному палив (табл. 6).

Таким чином, ризики, пов'язані зі зміною клімату, а також загострення проблем загального доступу до енергетичних ресурсів спонукають до активних процесів декарбонізації i розвитку зеленої енергетики. 
Сучасна траєкторія розвитку науково-технічного прогресу в Україні та світі

Україна володіє значним потенціалом зеленої енергетики. Загальний економічно-доцільний потенціал відновлюваних джерел енергії в Україні оцінюється приблизно в 454,4 млрд. кВт·год., або 59,2 млн. т у. п. на рік [37].

Таблиця 6

Встановлена потужність енергосистеми України станом на кінець 2020 року

\begin{tabular}{|c|c|c|}
\hline Тип електростанції & $\begin{array}{c}\text { Потужність, } \\
\text { МВт }\end{array}$ & $\begin{array}{c}\text { Питома вага у } \\
\text { загальній встановленій } \\
\text { потужності, \% }\end{array}$ \\
\hline Атомні електростанції & 13835 & 25,45 \\
\hline Теплові електростанції & 21842 & 40,18 \\
\hline $\begin{array}{c}\text { Теплові } \\
\text { електроцентралі }\end{array}$ & 6069,6 & 11,16 \\
\hline Гідроелектростанції & 4812,5 & 8,85 \\
\hline $\begin{array}{c}\text { Гідроакумулюючі } \\
\text { електростанції }\end{array}$ & 1487,8 & 2,74 \\
\hline Сонячні електростанції & 5061,6 & 9,31 \\
\hline Вітрові електростанції & 1070,7 & 1,97 \\
\hline $\begin{array}{c}\text { Біоенергетичні } \\
\text { електростанції }\end{array}$ & 186,1 & 0,34 \\
\hline
\end{tabular}

Сонячна енергія вже відіграє важливу роль в енергетичній системі країни, від невеликих побутових установок до масштабних проектів. В останні роки вартість сонячних панелей знижується. Через зменшення витрат та низькі викиди $\mathrm{CO}_{2}$ обсяги сонячних панелей будуть продовжувати зростати на основних ринках України та у всьому світі, сприяючи зростанню частки низьковуглецевої електрифікації.

Використання сонячної енергії можливе в трьох основних напрямках: великомасштабні сонячні електростанції, особливо там, де $\epsilon$ потенціал для використання наявної інфраструктури; децентралізовані рішення для сонячної енергії та приватні клієнти, які встановлюють сонячні панелі на дахах своїх будинків.

Завдяки великій кількості сонячних днів і помірній температурі повітря, встановлені на території України сонячні станції працюють максимально ефективно. Розвиток альтернативної енергетики стимулює також високий зелений тариф - для промислових сонячних електростанцій, побудованих у 2017-2019 рр., він становить 15 євроцентів; для сонячних 
Сучасна траєкторія розвитку науково-технічного прогресу в Україні та світі

електростанцій цивільного зразка - 18 євроцентів. Завдяки цьому та відносній доступності сонячних електростанцій їхній приблизний термін окупності в Україні становить 5-8 років [38].

Вітрова енергетика розвивається в Україні повільніше за сонячну. Головним чинником $\epsilon$ те, що вітрові електростанції в декілька разів дорожче за сонячні і мають більш складну технологію встановлення. При цьому вітрові електростанції потребують спеціального обслуговування і більших фінансових затрат.

Все більшу роль в паливному балансі України відіграє біоенергетика. Як відновлюване джерело енергії, біомаса при спалюванні виділяє лише стільки $\mathrm{CO}_{2}$, скільки вона зв'язала під час фази зростання. Окрім біогазу та біометану, під терміном «біомаса» також розуміють пожнивні рештки сільськогосподарських рослин, залишки деревини 3 лісових господарств, побічні продукти деревообробної промисловості, такі як тирса та необроблені деревні залишки, а також швидкоростучі енергетичні рослини.

Для того, щоб біомаса для виробництва енергії призводила до значного скорочення викидів $\mathrm{CO}_{2}$, її вирощування, виробництво та транспортування повинні бути контрольованими та екологічно безпечними.

Оцінка сумарних викидів парникових газів вимагає аналізу емісії протягом всього життєвого циклу біопалива. Вплив біопалива на зміну клімату залежить від сировини, 3 якої виробляється i яка справляє визначальний вплив на його хімічний склад і експлуатаційні характеристики. Значна роль в справі забезпечення енергетичної безпеки і запобігання зміни клімату відводиться розвитку біотехнологій, що не пов'язані 3 ризиками аграрного виробництва i не спричиняють загрозу продовольчої безпеки країни.

Використання біопалива з лігноцелюлозної сировини, може бути більш ефективним в плані зменшення викидів парникових газів, ніж сільськогосподарські культури. Значні перспективи має також біопаливо, отримане при переробці мікроводоростей. Висока здатність мікроводоростей до зв'язування атмосферного вуглекислого газу може позитивно впливати на вирішення проблеми парникового ефекту [39].

Згідно прогнозного сценарію «Енергетичної стратегії України до 2035 року» передбачається, що у структурі загального 
первинного постачання енергії частка відновлюваних джерел енергії буде становити 25 \% к 2035 року, а саме:

- біомаса, біопаливо та відходи - 11,5 \%;

- сонячна та вітрова енергія - 10,4 \%;

- гідроелектростанції - $1 \%$;

- термальна енергія - 2,1\%.

Отже, на сьогоднішній день, питання енергонезалежності України, раціонального споживання енергії і відповідно переходу до низьковуглецевого розвитку напряму залежать від нарощування потужностей зеленої енергетики.

Енергетичний перехід і розвиток нових засобів виробництва електроенергії вимагає інвестицій та створює додаткові витрати. У цьому контексті варто зазначити, що в Україні потрібні нові інвестиції в сектор електроенергетики усередньостроковій перспективі через значну зношеність основних фондів [40]. Інвестиції в сучасне обладнання, в розвиток технологій зеленої енергетики також мають потенціал до створення робочих місць $\mathrm{i}$ стимулювання економічного зростання

Крім цього використання відновлюваних джерел енергії і процеси декарбонізації виробництва, що призводять до зниження емісії парникових газів, дають також додатковий ефект у вигляді зменшення викидів інших шкідливих речовин. Це в першу чергу оксиди азоту, оксиди сірки, важки метали, неметанові органічні сполуки, тверді частки, які виділяються при споживанні бензину або при виробництві електроенергії 3 викопного палива. Скорочення викидів шкідливих речовин будуть сприяти покращенню екологічної обстановки, збереженню довкілля i здоров'я населення.

\section{Висновки}

Формування низьковуглецевої економіки $\epsilon$ викликом XXI століття і важливою умовою сталого розвитку. Досягнення цілей низьвуглецевого розвитку $\epsilon$ складним економічним, політичним, соціальним і технологічним процесом. Необхідними найважливішими умовами успішного рішення цього завдання $\epsilon$ наявність достатніх фінансових інвестицій, освоєння нових ефективних технологій, довгострокова плідна взаємодія та співробітництво країн світу. 
Сучасна траєкторія розвитку науково-технічного прогресу в Україні та світі

Зараз в Україні починається етап активного впровадження технологій 3 відновлюваними джерелами енергії, тому дуже важлива ефективна державна політика і державна підтримка.

Сприятливі природно-кліматичні умови України, ефективне залучення та використання інвестицій нададуть можливість в повній мірі реалізувати потенціал відновлюваної енергетики 3 метою забезпечення кліматичної стійкості і формування процесу економічного зростання та конкурентоспроможності в умовах низьковуглецевого розвитку.

За рахунок підвищення рівня інноваційних технологій і широкої підтримки заходів енергоефективності виникає можливість зниження обсягів викидів парникових газів та інших забруднюючих речовин, активного розвитку зеленої енергетики, поступової зміни енергетичної ситуації щодо надмірної залежності від викопного палива. Прискорення розвитку вітроенергетики та сонячної енергетики, а також використання біоенергетичного потенціалу без шкоди для продовольчої безпеки, буде сприяти диверсифікації енергоносіїв і поступовому збільшенню частки відновлюваних джерел енергії в енергобалансі країни. Що, відповідно $\epsilon$ запорукою енергетичної незалежності країни та буде спрямоване на забезпечення екологічної безпеки і сталий розвиток.

\section{Література:}

1. United Nations Framework Convention on Climate Change. Rio de Janeiro: United Nations, 1992. $24 \mathrm{p}$.

2. European Renewable Energy Council. URL: https://eurec.be/Policy-Papers (Last accessed: 27.09.2021).

3. International Labour Organization.URL: https://www.unaids.org/en/resources /publications/all (Last accessed: 28.09.2021).

4. Изменение климата, 2014. Обобщающий доклад. Межправительственная группа по изменению климата. Женева: МГЭИК. 2014. 163 с.

5. Stern N. The Economics of Climate Change. The Stern Review. UK: Cabinet Office-HM Treasury, 2006, URL: https://webarchive.nationalarchives.gov.uk/ukgwa/2010040717281 1/https:/www.hm-reasury.gov.uk/stern_review_report.htm (Last accessed: 28.09.2021). 
Сучасна траєкторія розвитку науково-технічного прогресу в Україні та світі

6. Butler J.H., Montzka S.A. The NOAA Annual Greenhouse Gas Index (AGGI), 2019. URL: http://www.esrl.noaa.gov/ gmd/aggi/aggi.html (Last accessed: 28.09.2021).

7. Статистический Ежегодник мировой енергетики 2021. URL: https://yearbook.enerdata.ru/co2/emissions-co2-data-fromfuel-combustion.html (дата звернення: 28.09.2021).

8. International Energy Agency. Global Energy Review 2020: the Impacts of the Covid-19 Crisis on Global Energy Demand and CO2 Emissions. April 2020. URL: https://webstore.iea.org/download/ direct/2995 (Last accessed: 29.09.2021).

9. Гао М. Низкоуглеродное производство: проблемы и выбор пути (на примере провинции Цзянси). Экономические $u$ социальные перемены: факты, тенденции, прогноз. 2015. № 4 (40). C. 171-179.

10. Warner E., Heath G. Life cycle greenhouse gas emissions of nuclear electricity generation: Systematic review and harmonization. Journal of Industrial Ecology. 2012. Vol. 16, № S1. P. S73-S92.

11. Renewable capacity statistics 2020. International Renewable Energy Agency, Abu Dhabi, IRENA, 2020.66 p.

12. Statistical Review of World Energy 2021. 70th edition. British Petroleum. London, 2021. 72 p.

13. Agora Energiewende and Ember. The European Power Sector in 2020: Up-to-Date Analysis on the Electricity Transition. Berlin. 2021. URL: https://static.agora-energiewende.de (Last accessed: 29.09.2021).

14. The European Green Deal. European Commission. Brussels, 11.12.2019. $24 \mathrm{p}$.

15. United Nations Framework Convention on Climate Change. FCCC/CP/2015/ L.9/ Rev.1 URL: https://unfccc.int/resource/docs/ 2015/cop21/eng/109r01.pdf (Last accessed: 29.09.2021).

16. United Nations Environment Programme. Emissions Gap Report 2020. Nairobi. UNEP. 2020. 128 p.

17. United Nations Framework Convention on Climate Change. Intended Nationally Determined Contributions (INDCs). 2021. URL: https://www4.unfccc.int/sites/

submissions/INDC/Submission\%20Pages/submissions.aspx (Last accessed: 30.09.2021).

18. Organisation for Economic Co-operation and Development (OECD). Green growth and sustainable development. URL: https://www.oecd.org/greengrowth/. 
Сучасна траєкторія розвитку науково-технічного прогресу в Україні та світі

19. Макаров И.А., Степанов И.А. Перспективі реализации стратегий низкоуглеродного развития ведучих стран. 08.04.2020. URL: https://we.hse.ru/climate/briefs (дата звернення: 30.09.2021). 20. BP Energy Outlook 2035. London, United Kingdom, January 2014. 96 p.

21. Smil V. Energy Transitions: History, Requirements, Prospects. Santa Barbara, Calif.: Praeger, 2010.178 p.

22. Smil V. Energy and Civilization: a History. Cambridge, MA: The MIT Press, 2018. 568 p.

23. Smil V. Energy Transitions: Global and National Perspectives, Santa Barbara, CA: Praeger. 2016. 282 p.

24. Fattouh B., Poudineh R, West R. The rise of renewables and energy transition: what adaptation strategy for oil companies and oilexporting countries? Oxford Institute for Energy Studies. 2018. 25 p.

25. Sovacool B.K., Geels, F.W. 'Further reflections on the temporality of energy transitions: A response to critics', Energy Research \& Social Science. 2016. 22. P. 232-237.

26. Agora Energiewende Energiewende 2030: The Big Picture. Megatrends,Targets, Strategies and a 10-Point Agenda for the Second Phase of Germany's Energy Transition. 2018. 82 p.

27. World Bank Group, State and Trends of Carbon Pricing. Washington DC, 2018. 62 p.

28. Концепція «Зеленого» енергетичного переходу України до 2050 року. Міністерство захисту довкілля та природних peсурсів. URL: https://mepr.gov.ua/news/34424.html (дата звернення: 01.10.2021).

29. Концепція реалізації державної політики у сфері зміни клімату на період до 2030 року. Розпорядження Кабінету Міністрів України від 07.12.2016 № 932. URL: https://mepr.gov.ua/news/32001.html (дата звернення: 01.10.2021).

30. Проєкт розпорядження Кабінету Міністрів України Про схвалення Другого національного визначеного внеску України до Паризької Угоди. Взято 3: https://mepr.gov.ua/files/images/2021/ 29042021 (дата звернення 02.10.2021).

31. Енергетична стратегія України на період до 2035 року «Безпека, енергоефективність, конкурентоспроможність». Розпорядження Кабінету Міністрів України від 18.08.2017, № 605-р. 73 с.

32. Стратегія низьковуглецевого розвитку України до 2050 року. Рішення Кабінету Міністрів України 18.07.2018 № 28. Київ. 53 с. 
Сучасна траєкторія розвитку науково-технічного прогресу в Україні та світі

33. Огляд енергетичного сектору України. Інституції, управління та політичні засади. OECD, 2019. URL: https://oe.cd/energy-sector-reform-ukraine (дата звернення: 04.10.2021).

34. Державна служба статистики України. URL: http://www.ukrstat.gov.ua (дата звернення: 04.10.2021).

35. CO2 emissions from fuel combustion. Global Energy Statistical. Yearbook 2021. Enerdata. URL https://yearbook.enerdata.net (Last accessed: 06.10.2021).

36. Average CO2 emission factor. Global Energy Statistical. Yearbook 2021. Enerdata. URL https://yearbook.enerdata.net (Last accessed: 06.10.2021).

37. Кучерява І.М., Сорокіна Н.Л. Відновлювана енергетика в світі та Україні станом на 2019 р. - початок 2020 р. Гідроенергетика України. 2020. № 1-2. С. 38-44.

38. Українська альтернативна енергетика: повільно, але стабільно. URL: https://bakertilly.ua/news/id44270 (дата звернення: 07.10.2021).

39. Litvak O., Litvak S. Some Aspects of Reducing Greenhouse Gas Emissions by Using Biofuels. Journal of Ecological Engineering, 2020. Vol. 21, iss. 8. P. 198-206.

40. Економічні наслідки поступової відмови від використання вугілля в Україні до 2030 року / М. Пройс, О. В. Михайленко, І. Сабака, Б. Пробст; за заг. ред. П. Баума та О. Р. Алієвої. Київ: 7БЦ, 2021. 140 с. 